\title{
Salt geology and mining traditions: Kalush and Stebnyk mines (Fore-Carpathian region, Ukraine)
}

Geologia salinarna i górnicze tradycje: kopalnie w Kałuszu i Stebniku (Przedgórze Karpat, Ukraina)

\author{
Krzysztof Bukowski ${ }^{1}$ \& Grzegorz Czapowski ${ }^{2}$ \\ ${ }^{1}$ Akademia Górniczo-Hutnicza,ul.Al.Mickiewicza 30,30-059Kraków, e-mail:buk@agh.edu.pl \\ ${ }_{2}^{2}$ Państwowy Instytut Geologiczny-Państwowy Instytut Badawczy, ul. Rakowiecka 4, 00-975 Warszawa; \\ e-mail: grzegorz.czapowski@pgi.gov.pl
}
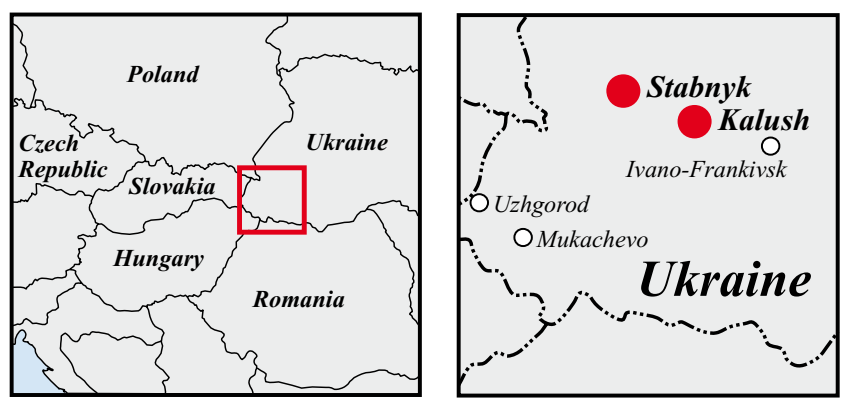

Abstract: Development of industrial underground salt mining in western Ukraine has started in the mid-19th century with the discovery of large potash-magnesium salt deposits in Kalush (1854) and Stebnyk (1901). Potash salts concentrations occur within the Miocene sedimentary complexes of Ukrainian Carpathian Foredeep (correlated with the successions observed in the Polish part of Carpathian Foredeep) as isolated lenses or compressed folded layers of varied extent. Thickness of exploited potash seams varies from $4 \mathrm{~m}$ up to $150 \mathrm{~m}$ and the main mineral is sylvine, accompanied also by carnallite, kainite and langbeinite. Both Kalush and Stebnyk mines, now closed, belong to the first places in the world, where exploitation of potash salts were realized. Their unique historical character, documenting the salt exploitation traditions in this region and evolution of mining techniques, ought to be widely advertised as the valid points of Ukrainian-Polish cross-border geotouristic route, named "Traces of large extinct mammals, earth wax, oil and salt".

Key words: salt deposits, geology, exploitation, Kalush mine, Stebnyk mine, Miocene, Ukraine

Treść: Rozwój podziemnego górnictwa solnego na obszarze zachodniej Ukrainy rozpoczat się w połowie XIX wieku w momencie odkrycia dużych złóż soli potasowo-magnezowych w Kałuszu (1854), a później w Stebniku (1901). Nagromadzenia soli potasowych występuja tu w postaci odrębnych soczewek lub zmiętych sfatdowanych warstw o zmiennym rozprzestrzenieniu. Miaższość eksploatowanych pokladów soli potasowo-magnezowej zmienia się od $4 \mathrm{~m}$ do maksymalnie $150 \mathrm{~m}$. Kopalinę stanowit głównie sylwinit, poza tym $w$ złozach eksploatowano karnalit, kainit i langbajnit. Obydwie kopalnie w Katuszu i Stebniku sq jednymi z pierwszych w świecie miejsc, gdzie rozpoczęto eksploatacje soli potasowo-magnezowych. Ich unikatowy historyczny charakter zastuguja na przypomnienie i rozpropagowanie jako ważne miejsca polsko-ukraińskiej transgranicznej trasy geoturystycznej od Staruni do Krakowa , Szlakiem wielkich wymarlych ssaków, wosku ziemnego, ropy naftowej i soli". Stowa kluczowe: złoża soli, geologia, eksploatacja, kopalnia Kałusz, kopalnia Stebnik, miocen, Ukraina

\section{Introduction}

From the pre-historical up to the medieval time the salt production in the area of western Ukraine was based on evaporation of salt brines (waters with mineralization over 4-5 g/l, containing mainly sodium and chlorides; Kleczkowski, 1981). Such mineralized waters, after sufficient concentration, were used in salt-works. Their occurrences as springs and shallow digged wells in the times of Polish Kingdom were mentioned in numerous old descriptions and notations (e.g. Staszic, 1815; Pusch, 1831-1836; Alth, 1871; Szajnocha, 1891, 1893; Zaręczny, 1894; Kamiński, 1911a, 1911b; Bukowski \& Jackiewicz, 1926; Windakiewicz, 1926, 1939; Jodłowski, 1971).

After historical data (Windakiewicz, 1926, 1939) salt springs were noticed in 196 sites located in the foreland of the Polish and Ukrainian Carpathians. In 1773 in the area of western Ukraine were registered 92 active salt-works (called Ruthenian salt-works), which produced over 40 thousands tonnes of salt per year. Some of these sites were located in the Carpathians and the source salt brines came from the flysch complexes (intra-Carpathian brines) but the most of them are the sub-Carpathian brines, grouped in the Fore-Carpathian region and coming from the Miocene saltbearing series. This series occurs at the small depth eastward from Przemyśl and continues as a belt ca. $235 \mathrm{~km}$ long and up to $20 \mathrm{~km}$ wide along the SE margin of the Carpathians, from Sambir, Drohobych, Stryi, Bolekhiv, Dolyna, Delyatyn and Kosiv up to the boundary with Romania (Fig. 1). The underground rock salt mining accompanying the brine exploitation from very early time is evidenced by findings of flint tools and axes as well as Hadrian's coins in corridors of old salt-work in Utropy near Kolomyia (Windakiewicz, 1939).

Development of underground salt mining in the western Ukraine has started in the mid-19th century with the discovery of large potash-magnesium salt deposits in Kalush (1854), and Stebnyk (1901). Both these mines are the one of the first places in the world, where exploitation of potash salts were realized and due to their unique historical character ought to be widely advertised as the valid points of Ukrainian-Polish trans-border geotourist trail, named "Traces of large extinct mammals, earth wax, oil and salt" (Kotarba, 2009). 


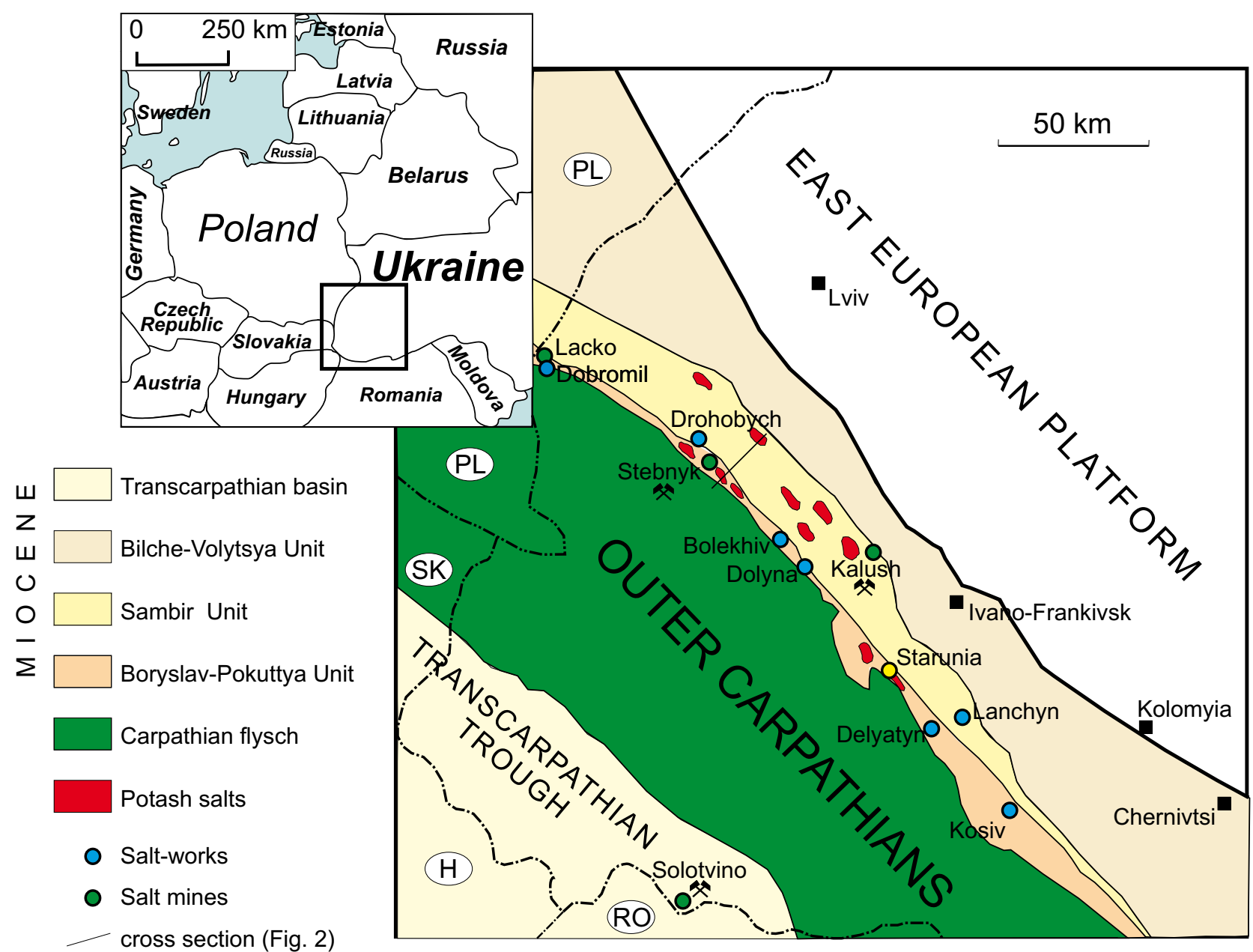

Fig. 1. Distribution of potash and rock salt deposits (red areas, salt mines marked) in background of regional geological structure of western Ukraine (after Hryniv et al., 2007). The salt-works existed directly before the World War II also indicated (after Windakiewicz, 1939) • Rozmieszczenie złóż soli potasowych i kamiennych na tle geologii regionalnej zachodniej Ukrainy (wg Hryniv et al., 2007). Kolorem czerwonym zaznaczono złoża. Na mapce kółkami zaznaczono również warzelnie i kopalnie działające bezpośrednio przed wybuchem II wojny światowej (wg Windakiewicza, 1939)

\section{Geological setting}

Miocene salt deposits (Fig. 1) occur in the western Ukraine within two structural units (e.g. Kityk, 1979; Kityk et al., 1971, 1983; Koriń, 1994; Petryczenko et al., 1994): (I) Carpathian Foredeep (rock and potash salt) and (II) Transcarpathian trough (rock salt). These salt-bearing deposits differ in the thickness and lithology depending on the regional tectonic location (Czapowski et al., 2009). In the Ukrainian part of Carpathian Foredeep, three main tectonic zones were distinguished (Figs 1, 2): (I) outer zone (Bilche-Volytsya Unit), in which the Miocene molasse deposits overlie discordantly the Mesozoic platform basement at the depth of 10-200 m, and in the foredeep they subsided under the overthrust of the Sambir zone and are at depths of 1.2-2.2 km (Hryniv et al., 2007); (II) central zone (Sambir Unit), in which the Miocene deposits were overthrusted onto the external part of the Foredeep on the distance of 8-12 $\mathrm{km}$ and the deposits of the external zone occur at the depth of 1.0-2.2 km; (III) internal zone (Boryslav-Pokuttya Unit), in which the Miocene deposits were overthrusted onto the Sambir Nappe zone on the distance of $25 \mathrm{~km}$ (Hryniv et al., 2007).
Carpathian Foredeep has formed in the Early Miocene, northwards from emerging the Outer (Flysch) Carpathians. This basin was filled with Miocene siliciclastic deposits (clays, claystones, sandstones and conglomerates) with max. thickness of $3 \mathrm{~km}$ in Poland and up to $5 \mathrm{~km}$ in Ukraine (Oszczypko, 2006). Two main evaporite formations (ukr. svity; Hryniv et al., 2007; Petryczenko et al., 1994), occur: (I) Vorotyshcha Beds, dated as Late Eggenburgian and Ottnangian, 1.1-2.3 $\mathrm{km}$ thick, is composed of clays with sandstones, rock and potash salt interbeds (Petryczenko et al., 1994; AndreyevaGrigorovich et al., 2008). This suite was subdivided into two parts (subsuites): the lower one 100-900 m thick with rock salt beds and the upper one $0.7-1.0 \mathrm{~km}$ thick with beds of potash salts (Hryniv et al., 2007). In the latter subsuite, in the area of Boryslav-Pokuttya Nappe, close to the Carpathian overthrust, the large Stebnyk rock and potash salt deposit occurs (Figs 1-3); (II) Tyras Beds of Badenian age attains the thickness of 300-800 $\mathrm{m}$ in the Sambir Unit and consists of salt breccias and rock and potash salts. In the BilcheVolytsya Unit deposits varies from $20-70 \mathrm{~m}$ and contains claystones, sandstones, carbonates, sulphates and rock salts. 

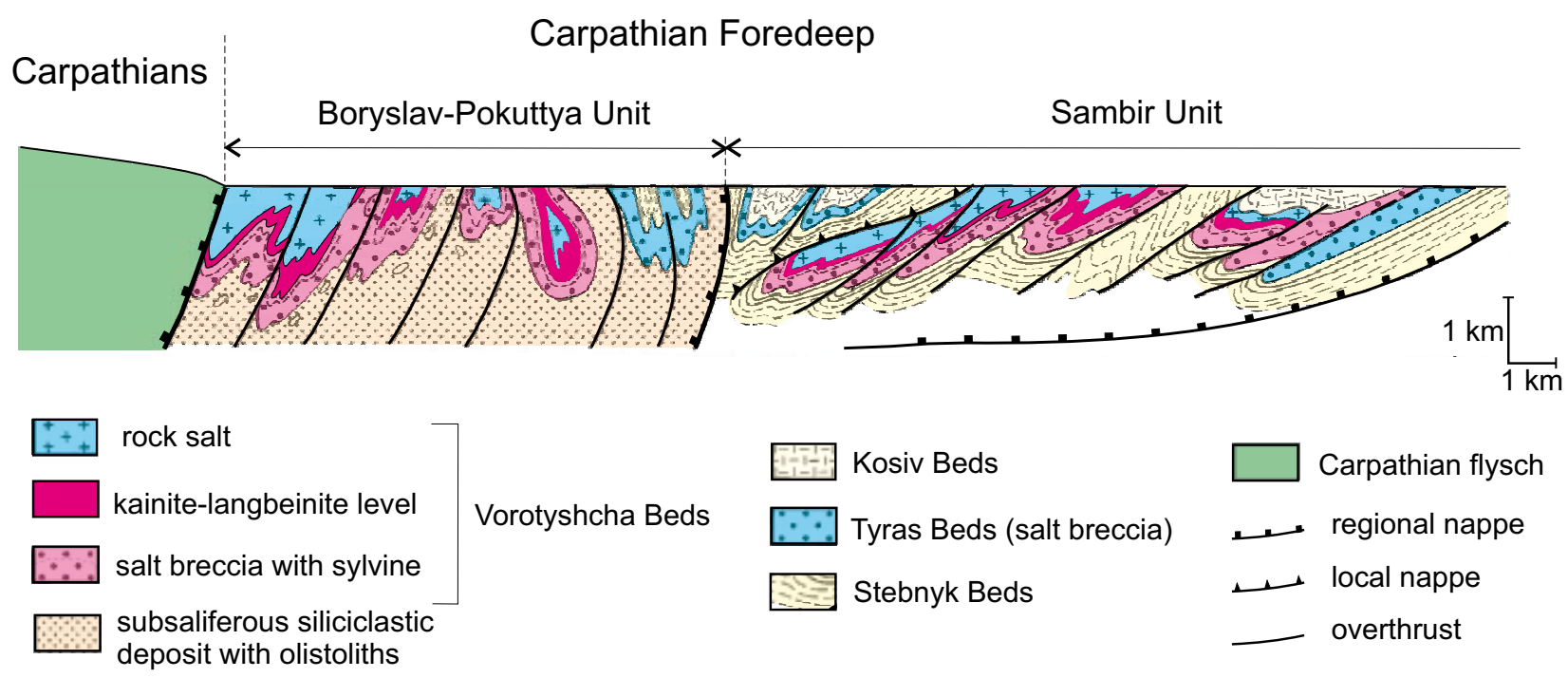

Fig. 2. Geological cross-section of Carpathian Foredeep near Stebnyk (after Koriń, 1994) • Przekrój geologiczny przez zapadlisko przedkarpackie w pobliżu Stebnika (wg Korinia, 1994)

Within the Tyras Beds the Kalush suite (200-400 m thick) occur; they are composed of salty clays, potash salts, sulphates and clay sandstones laterally replaced by rock salts $25 \mathrm{~m}$ thick and anhydrites up to $250 \mathrm{~m}$ thick (Petryczenko et al., 1994). These beds are correlated with the Wieliczka Formation in the Polish part of the Carpathian Foredeep (Fig. 3; Andreyeva-Grigorovitch et al., 2003). Within the Tyras Beds in area of the Sambir Nappe zone is located the Kalush salt deposit (Fig. 1) characterized by nappe-fold structure (Koriń, 1994).

The salt-bearing deposits up to $500 \mathrm{~m}$ thick, attributed earlier (Petryczenko et al., 1994) to the Stebnyk Beds and dated as the Ottnangian, were included by S. S. Koriń (1994) to the Tyras Beds (Fig. 3).

Rock salts of the Carpathian Foredeep are characterized in general by high clay content (up to 50\%; Bukowski \& Jackiewicz, 1926). Potash salt concentrations occur as isolated lenses or compressed folded layers of varied extent. Thickness of exploited potash seams varies from $4 \mathrm{~m}$ up to $150 \mathrm{~m}$ and the main mineral is sylvine, accompanied by carnallite, kainite and langbeinite (Koriń, 1994).

\section{Kalush potash salt deposit}

Thickness of Miocene deposits near Kalush attains $1 \mathrm{~km}$. Two local salt units (beds) were distinguished within the major Tyras Beds: the Kalush and Holyn suites, occurred in the nucleus of Miocene deposits of Sambir Unit overthrusted onto the Mesozoic and Middle to Upper Miocene molasse sediments of the outer (Bilche-Volytsya) tectonic unit. The Kalush Beds, 50-170 m thick, is composed mainly of clays with sandstone and mudstone intercalations but the Holyn suite consists of clayey rock salts (30-60\% of clay), salty clays and claystones (Koriń, 1994). Repeated interbeds and concentrations of potash salts up to several meters thick are defined as separate potash salt fields. Such salt seams represent several mineralogical types: kainite, langbeinite-kainite, langbeinite, sylvine and uncommon - carnallite and polyhalite types. These components are accompanied by anhydrite, kieserite and carbonates. The potash fields occur most often in tectonic troughs within larger synclines, commonly at the depth of 100-150 m, max. $800 \mathrm{~m}$.

First notations on salt production from brines in Kalush are dated for the 15th century. Existence of salt-works at those time was confirmed by the privilege by the king Kazimierz Jagiellończyk from 5th April 1496. After historical notations salt was initially obtained from the small salt ponds, called a "kalush" so the supposed provenience of the site name.

In 1571 in Kalush existed three salt-works with 2 shafts ("Mogiła" and "Szczypiotka"), being the royal property and - similarly as the Cracow salt-works - were hired to the rich nobles. After Austrian rape of Galicia and introduction of salt monopoly the government has bought from privates all salt shafts and salt-works. The Kalush salt-work was bought from Stanislaw Lubomirski and Adam Czartoryski by the Austrian government in 1782. Its further intensive development initiated in the middle of 19 th century, with discovering of sylvine - a fundamental mineral of potash salts - in 1854 in Wiesner salt-work (Fig. 4). Presentation of this finding by Prof. H. Rose during the session of Geological Association in Berlin, was the trigger for potash salts exploitation in 1867 (Windakiewicz, 1926). Development of mineralogical science in the 19th century was also related to Kalush, where were discovered and described such evaporite minerals as syngenite $\left[\mathrm{K}_{2} \mathrm{Ca}\left(\mathrm{SO}_{4}\right)_{2} \times \mathrm{H}_{2} \mathrm{O}\right]$ initially called kalushite (Rumpf, 1872), kainite (Hauer, 1870) just after its finding in Germany, and sylvine (Windakiewicz, 1871). Two years later the processing plant was founded nearby the Kalush potash salt mine as well as the separate plant for potash saltpetre production in Simmering near Vienna. 


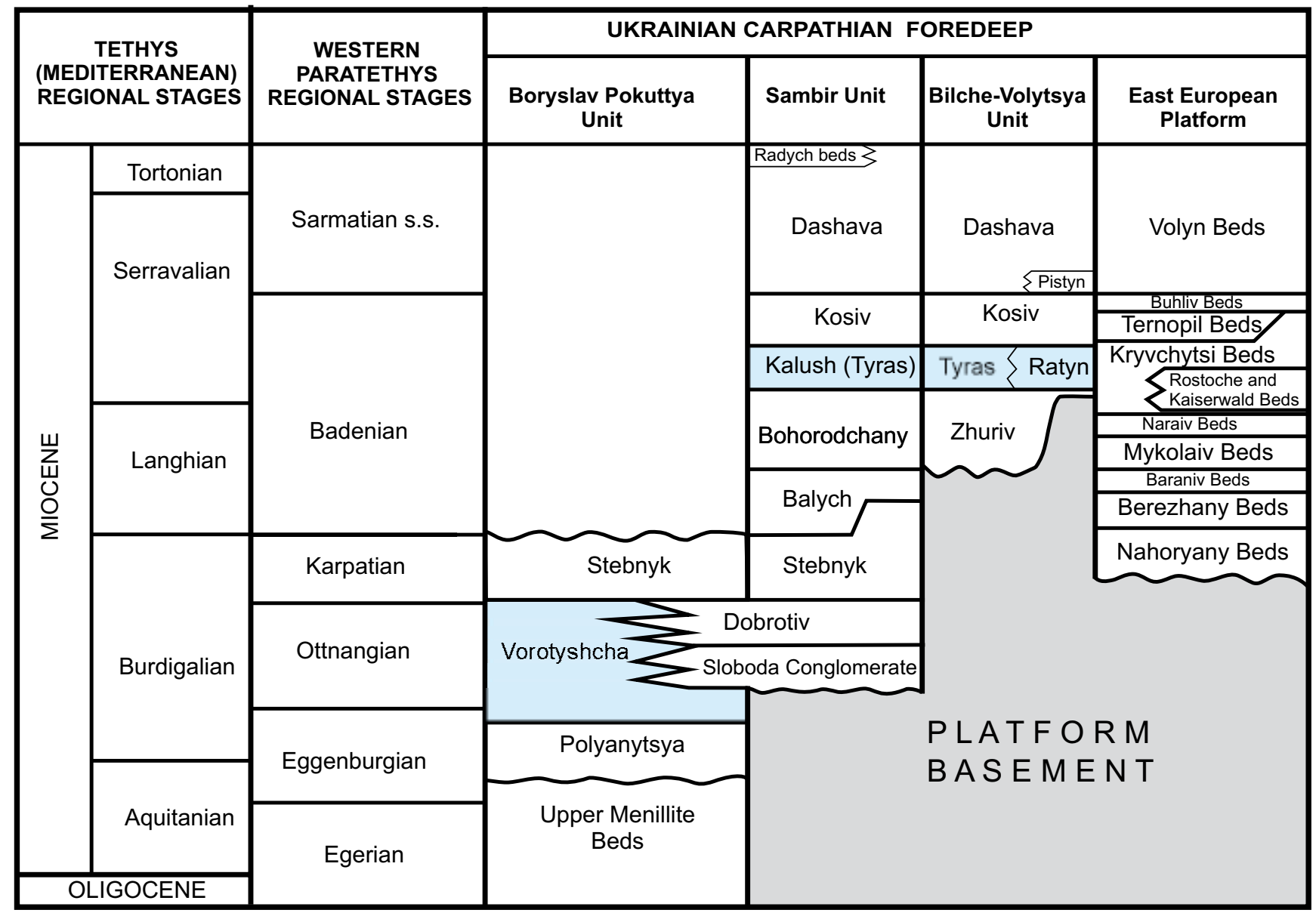

Fig. 3. Simplified Miocene stratigraphy of Ukrainian Carpathian Foredeep (compiled after Petryczenko et al., 1994; Andreyeva-Grigorovich et al., 2008) • Uproszczona stratygrafia miocenu ukraińskiej części zapadliska przedkarpackiego (zestawiona na podstawie Petryczenko et al., 1994; Andreyeva-Grigorovich et al., 2008)

From this moment the Kalush mine focused on exploitation of potassium-magnesium salts. During the long history of production six mining areas and nine exploitation fields for potash salts were contoured and managed (Figs 5, 6).

The Society for the Exploitation of Potassium Salt (TESP -Lwów) $)^{1}$ managed the mine, patronised also the local development of art and culture (Poborska-Młynarska \& Andrusikiewicz, 2010). Polish cultural life concentrated in "Sokół" Society, which had its own building with a showroom and gymnastic-club rooms and utilities. The mine also financed the active Dramatic Society.

After the World War II the underground mining was continued as several variants of chamber system, with deposit sectioning for levels and stages (Permiakov et al., 1981). Chambers done in the 1980 s were $10 \mathrm{~m}$ wide and the separating pillars $-7.7 \mathrm{~m}$. Chamber height depended on thickness of exploited seam and varied from a dozen or so up to $30 \mathrm{~m}$. Chambers were excavated in two levels, drilling blasting wells and crushing the rock with explosives (Czapowski et al., 2009, Poborska-Młynarska \& Andrusikiewicz, 2010).

In the second half of the 20th century exploitation of rock and potash salts was initiated in the open-pit Dombrowo, located SW from Kalush, where these salts occurred just under the surface (Fig. 7). Because of the increased mining menaces (water inflows) and gradual exhausting of salt resources the mines in Kalush became stopped.

\section{Stebnyk potash salt deposit}

The potash salt deposit in Stebnyk is related to the Miocene Vorotyshcha Beds (Figs 1-3). Salt-bearing deposits were traditionally attributed to two main rock complexes (Lower and Upper Vorotyshcha Beds) separated by terrigenous (sandstones and conglomerates) Zahirsk Beds (Petryczenko et al., 1994). Several papers of last years indicated that $\mathrm{Za}$ hirsk Beds belonged to the olistostrome horizon (submarine slump, interrupting evaporite deposition) and there were no arguments for subdividing the Vorotyshcha Beds into two subunits (Hryniv et al., 2007).

In the Stebnyk deposit the salt-bearing series are multiplied (Fig. 2) and their summary thickness up to $2,000 \mathrm{~m}$ resulted from intensive folding and overthrusting of Carpathians foredeep. More plastic salts became then compressed and squeezed into the centres of synclinal folds forming the lens-shape bodies (Fig. 2). These bodies are often several hundreds meters wide and occur at the depth of 80-650 $\mathrm{m}$, commonly at 100-360 m (Werner, 1977).

The lower part of Vorotyshcha Beds is build of salt-bearing breccia (Koriń, 1994), containing in its upper section the sylvine or carnallite intercalations (Fig. 8) and numerous blocks of folded marly clays. Above occurs the potash-bearing series (Fig. 8) 10-125 m thick, composed of beds of kainite, langbeinite and lagbeinite-kainite association with 
imprints of sylvine and kieserite (Hryniv et al., 2007). The potash seam is overlain by the rock salt complex $60 \mathrm{~m}$ thick (Koriń, 1994).

Genesis of Stebnyk salt-work is unknown and only sure data inform that it was owned by the count Seweryn Rzewuski and from 1773 was owned by the Austrian government.

After the 19th century press news (Pusch, 1844; Wiadomość..., 1844) the large rock salt deposits in Stebnyk were discovered before 1844 . Salt leaching in the mine was initiated in 1854 and brine analyses (in salt-plant "Bruck") evidenced - among other components - content of potassium and magnesium chlorides and magnesium sulphate (Windakiewicz, 1939). Prospection for K-Mg salts was then unsuccessful. Just in 1901 the prospection works directed by ing. Edward Windakiewicz finalized with discovery of potash salts, enabling further activity of the Stebnyk mine. In next years there were recognized and contoured four potash salt seams (Figs 9-10), composed of langbeinite, kainite and partly of sylvine (Windakiewicz, 1926, 1939).

After the Word War I, the Polish government rented the Stebnyk mine to the Society for the Exploitation of Potassium Salt (TESP-Lwów), which started the prospection works and drillings in the mine and in surroundings of Stebnyk (Figs 11, 12). These efforts resulted in discovery of large potash seams e.g. at Boryslav, Dobrohostiv, Uchlychne and Holyn. Before the Word War II, TESP has founded - except the mines in Stebnyk and Kalush - the third potash salt mine in Holyn at Kalush and started the processing plant of langbeinite $\left(\mathrm{K}_{2} \mathrm{SO}_{4}\right.$ × $\left.2 \mathrm{MgSO}_{4}\right)$ into magnesium oxygen $(\mathrm{MgO})$, potassium sulphate $\left(\mathrm{K}_{2} \mathrm{SO}_{4}\right)$ and sulphur $(\mathrm{S})$.

In the post-war years the prospecting was continued and 14 distinct lenses of potash salts were contoured (Hryniv et al., 2007). Total resources of sulphate potash salts in western Ukraine were calculated at 15 x 109 tonnes in 1963. Maximum potash salt production was achieved in the sixties of the last century when the Stebnyk and Kalush mines delivered $150 \mathrm{x}$ 106 tonnes of $\mathrm{K}_{2} \mathrm{O}$ and the New Stebnyk salt-work $-250 \mathrm{x}$ 106 tonnes of $\mathrm{K}_{2} \mathrm{O}$ as $\mathrm{K}_{2} \mathrm{SO}_{4}$ compound per year (Werner, 1977).

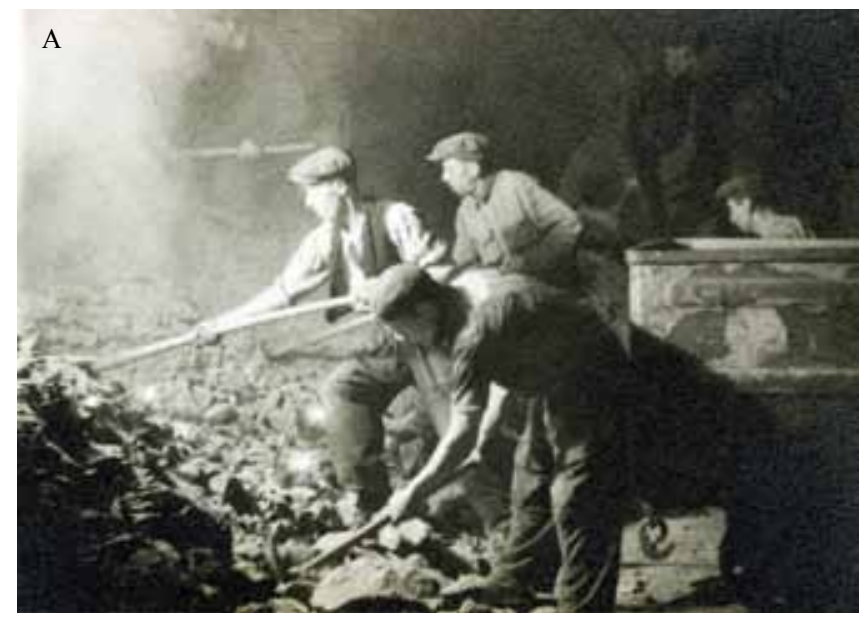

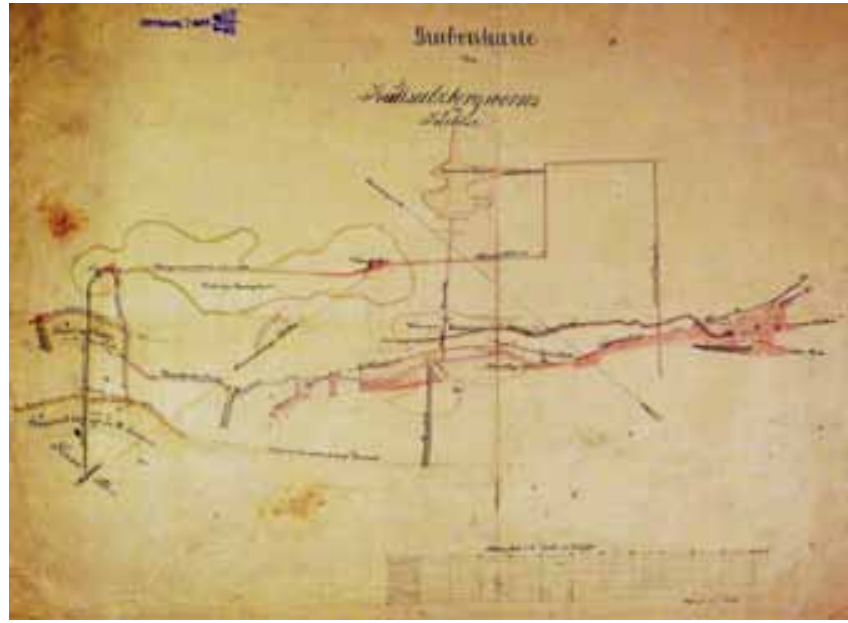

Fig. 4. Map of underground excavations in the Kalush mine after Webner (1872). In the center is marked the Wiesner chamber, the first one in which potash salts were discovered. Collection of Museum of Cracow Salt-Works at Wieliczka Photo by K. Kozłowski • Mapa wyrobisk podziemnych w kopalni w Kałuszu autorstwa Webnera (1872). W centrum mapy zaznaczono komorę Wiesner, w której po raz pierwszy odkryto sole potasowe. Mapa ze zbiorów Muzeum Żup Krakowskich, Wieliczka. Fot. K. Kozłowski

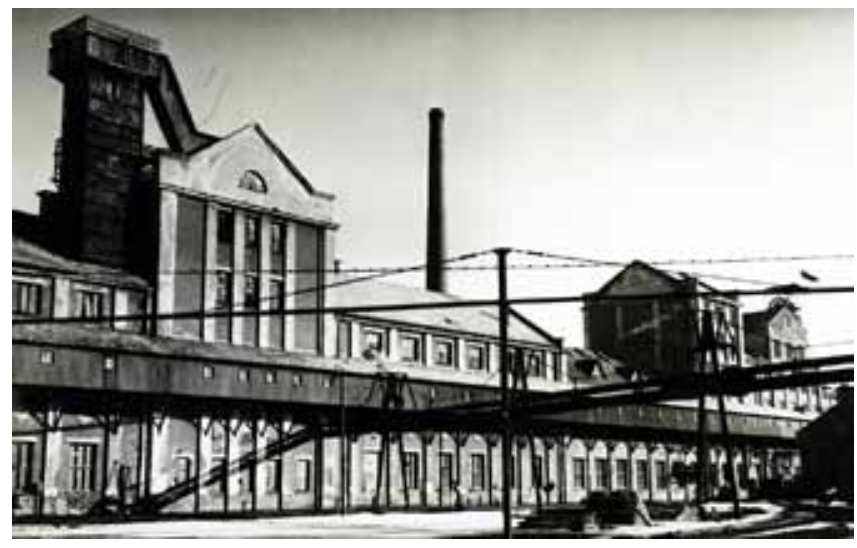

Fig. 5. General view of salt mine in Kalush on the postcard in the period between World War I and II. Collection of Museum of Cracow Salt-Works at Wieliczka • Widok ogólny na kopalnię soli w Kałuszu, lata międzywojenne. Pocztówka ze zbiorów Muzeum Żup Krakowskich, Wieliczka

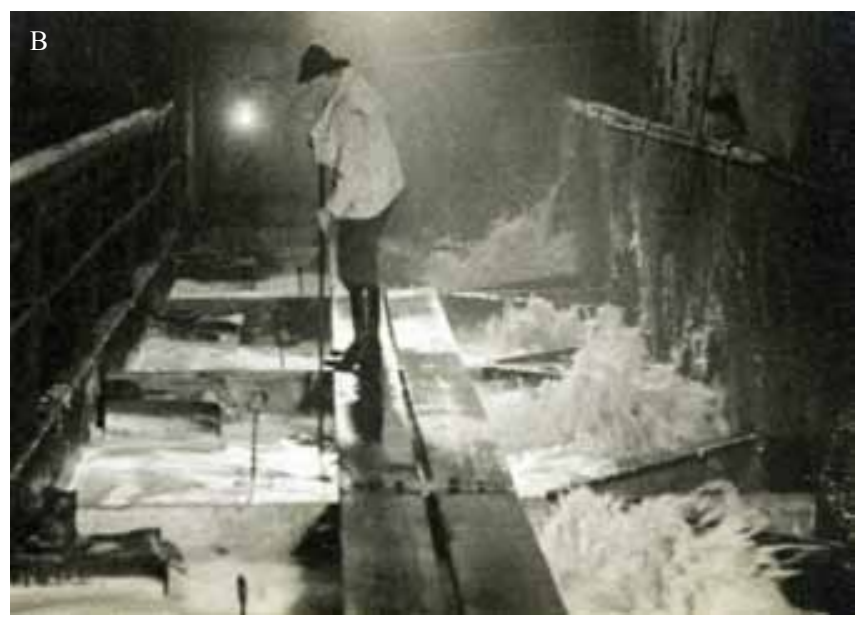

Fig. 6. The Kalush salt mine in the period between World War I and World War II. A - miners at work, B - underground leaching chamber (photos from the collection of Museum of Cracow Salt-Works at Wieliczka) • Kopalnia soli Kałusz, lata międzywojenne; A - górnicy przy pracy, B - podziemna komora ługownicza (fotografie ze zbiorów Muzeum Żup Krakowskich, Wieliczka) 
Potash salts exploitation was finished in the Stebnyk mine recently, leaving the total volume of post-exploitation underground cavities estimated for $33 \mathrm{mln}^{3}$. They are the serious problem for the environment generating field surface deformations and depressions as well as accelerating karst processes (Kulyniak, 2002). In 1983 there was a serious ecological catastrophe (Stebnyk catastrophe) when over 5 million $\mathrm{m}^{3}$ of industrial brines inflowed into the Dnister River.

Both described salt mines of western Ukraine are the valid points of the cross-border geoturistic route, dedicated to the common geological history and mining traditions in the Polish-Ukrainian foreland. Preserved material remnants as well as historical notations, documenting many centuries of salt prospecting and mining in this region, are the common historical heritage of both countries, enhancing the periods of common history when the salt resources and their exploitation were a fundamental part of the nations prosperity.

Acknowledgments. Authors are very grateful to Katarzyna Poborska-Młynarska and Andrey Poberezhskyy for kindly

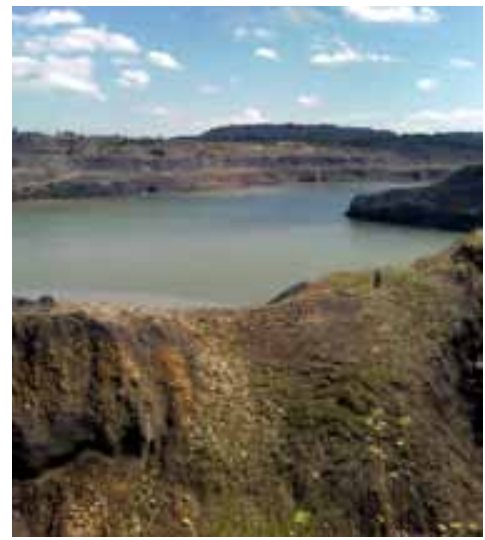
discussions and photos to present in the paper. Museum of Cracowian Salt-Works is thanked for presented photos and copies of archive map from Kalush. Many thanks are to the Reviewers of the paper: Prof. Nestor Oszczypko and Prof. Tadeusz M. Peryt for helpful remarks and comments to the manuscript. $\square$

Fig. 7. View of the past open-pit of potash salts in Dombrowo at Kalush. Photo by A. Poberezhskyy • Obecny widok na odkrywkę soli potasowych Dombrowo w Kałuszu. Fot. A. Poberezhskyy

\section{Streszczenie \\ Geologia salinarna i górnicze tradycje: kopalnie w Kałuszu i Stebniku (Przedgórze Karpat, Ukraina)}

\section{Krzysztof Bukowski, Grzegorz Czapowski}

Produkcja soli w czasach przedhistorycznych aż do średniowiecza na obszarach zachodniej Ukrainy oparta była na eksploatacji solanek. Ich występowanie w postaci źródeł lub w płytkich studniach kopanych na terenach dawnej Rzeczypospolitej było przedmiotem wzmianek i opisów od bardzo dawnych czasów. Na podstawie danych historycznych źródła słone występowały w 196 miejscowościach położonych na przedpolu polskiej i ukraińskiej części Karpat. Część tych miejscowości była położona w obrębie Karpat i solanki tam występujące związane były ze skałami fliszowymi (solanki śródkarpackie). Przeważająca jednak większość solanek to solanki podkarpackie grupujące się na Pogórzu Karpackim. Są one związane z mioceńską serią solonośną, która na niewielkich głębokościach występuje na wschód od Przemyśla i ciągnie się nieprzerwanym pasem na długości ok. $235 \mathrm{~km}$, szerokości do $20 \mathrm{~km}$ wzdłuż południowo-wschodniego brzegu Karpat przez okolice Sambora, Drohobycza, Stryja, Bolechowa, Doliny, Delatyna i Kosowa aż do granicy rumuńskiej (Fig. 1). Równolegle $\mathrm{z}$ eksploatacją solanek prowadzono na niewielką skalę podziemną eksploatację soli kamiennej i to również od bardzo zamierzchłych czasów. Świadczyć mogą o tym znalezione $w$ starych zrobach dawnej żupy solnej w Utropach koło Kołomyi monety z czasów cesarza Hadriana, topory z rogowca i narzędzia z krzemienia.

Rozwój podziemnego górnictwa solnego na obszarze zachodniej Ukrainy rozpoczął się w momencie odkrycia w połowie XIX wieku dużych złóż soli potasowo-magnezowych w Kałuszu (1854), a później w Stebniku (1901).
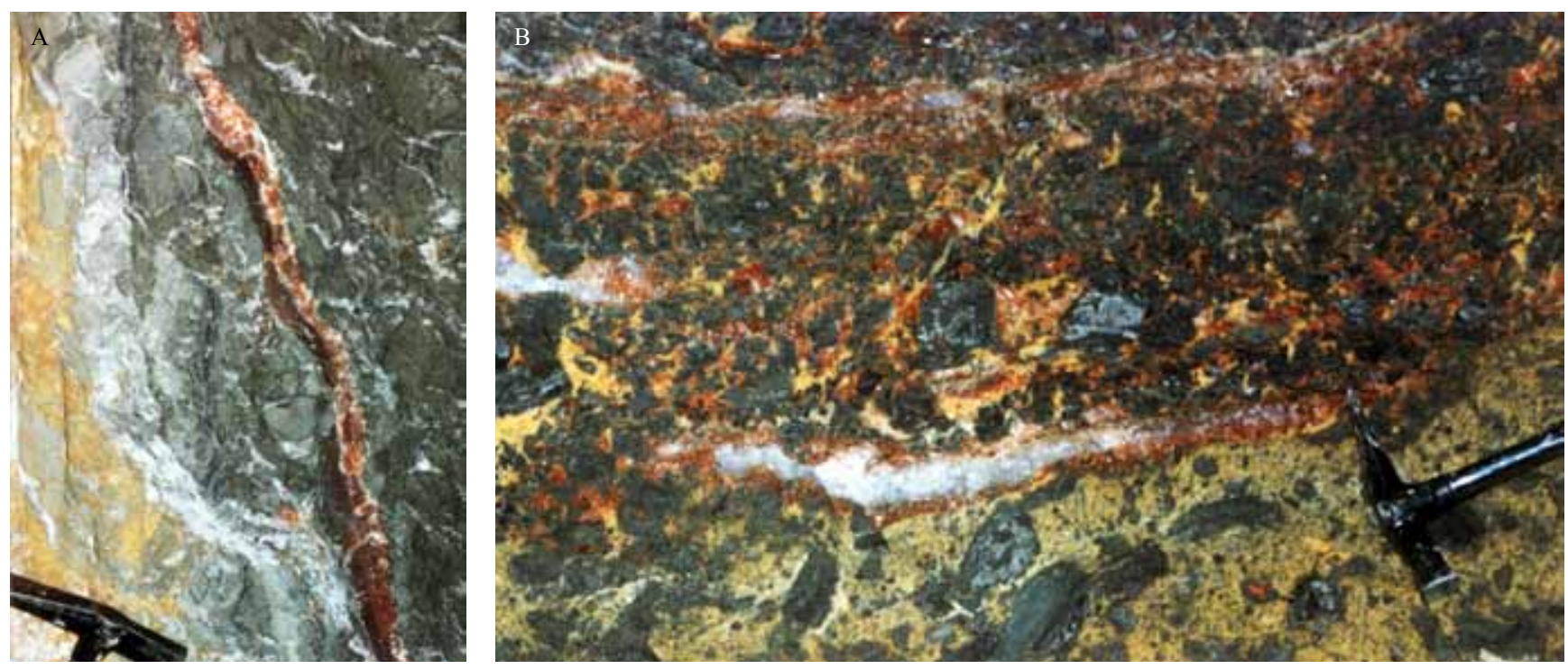

Fig. 8. Potash salts from the Stebnyk mine. A - Kainite vein (red) within the marly clay complex. Vorotyshcha Beds, Eggenburgian-Egerian, Stebnyk mine, B - Nest of carnallite (red) and sylvine (white) salts within the marly-clay breccia. Vorotyshcha Beds, Eggenburgian-Egerian, Stebnyk mine. Photo by G. Czapowski • Sole potasowo-magnezowe z kopalni w Stebniku. A - Żyła kainitu (czerwona) w obrębie iłów marglistych. Warstwy worotyszczańskie, eggenburg-eger, kopalnia soli w Stebniku, B - Gniazda karnalitu (czerwony) i sylwinu (biały) w obrębie marglisto-ilastej brekcji. Warstwy worotyszczańskie, eggenburg-eger, kopalnia soli w Stebniku. Fot. G. Czapowski 
Nagromadzenia soli potasowych występują tu w postaci odrębnych soczewek lub zmiętych sfałdowanych warstw o zmiennym rozprzestrzenieniu (Fig. 2, 3). Miąższość eksploatowanych pokładów soli potasowo-magnezowej zmienia się od $4 \mathrm{~m}$ do $150 \mathrm{~m}$ maksymalnie. Kopalinę stanowił głównie sylwinit, poza tym w złożach eksploatowano karnalit, kainit i langbajnit. Obydwie kopalnie w Kałuszu i Stebniku sąjednymi z pierwszych w świecie miejsc, gdzie prowadzono eksploatację soli potasowo-magnezowych, opisywano nowo odkryte minerały (Fig. 4), a zarządzające kopalniami w latach między I a II wojną światową Towarzystwo Eksploatacji Soli Potasowych (TESP-Lwów) było mecenasem sztuki, kultury i sportu (Fig. 5-6, 8-12).

Obecnie w obydwu kopalniach zakończono eksploatację (Fig. 7), ze względu jednak na swój unikatowy historyczny charakter zasługują na przypomnienie i rozpropagowanie w formie punktów polsko-ukraińskiej transgranicznej trasy geoturystycznej od Staruni do Krakowa „Szlakiem wielkich wymarłych ssaków, wosku ziemnego, ropy naftowej i soli”.

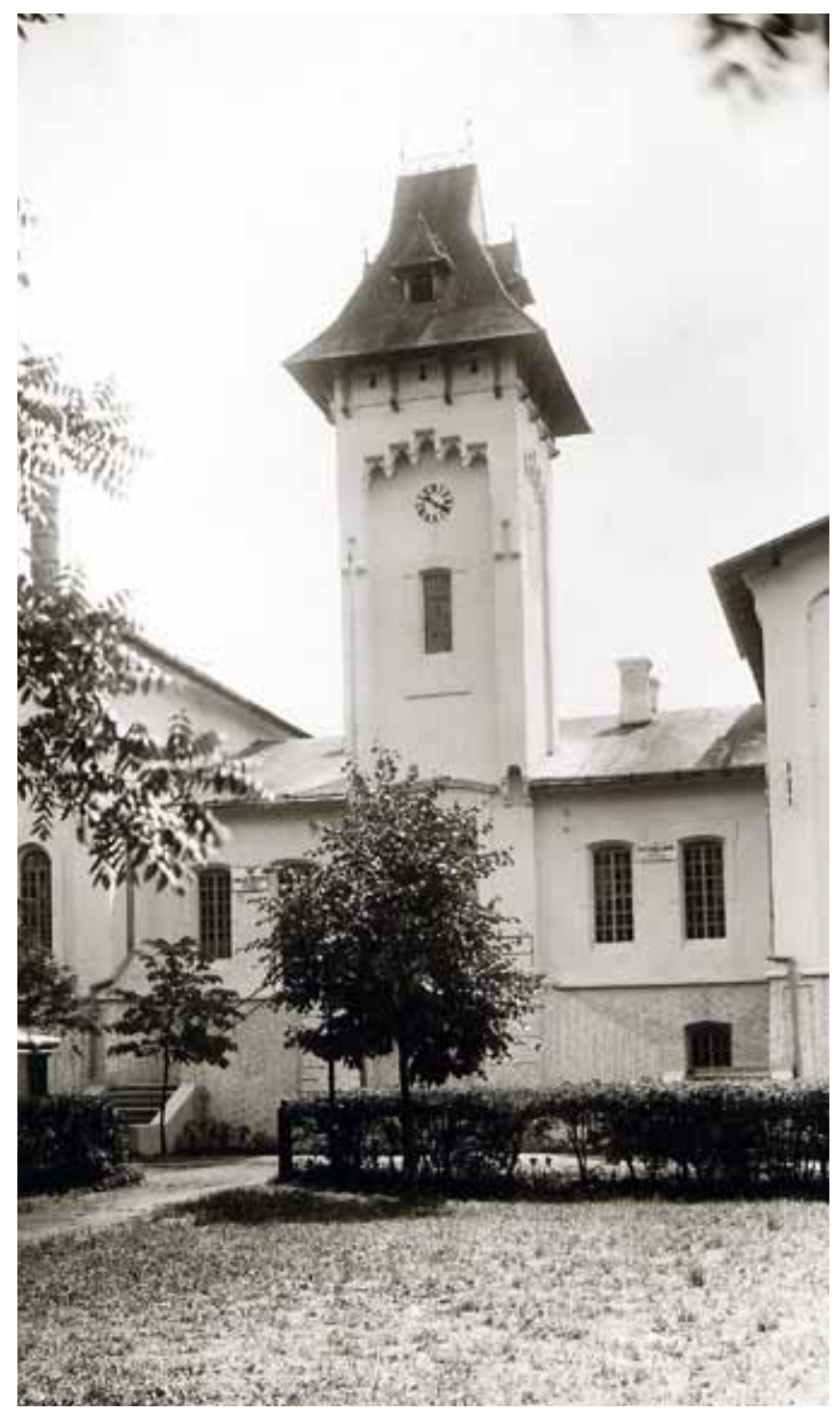

Fig. 11. View of main building of Stebnyk mine - the period between World War I and II. Photo from private archive of Prof. J. Poborski - Widok głównego budynku kopalni w Stebniku - lata międzywojenne. Fot. z prywatnego archiwum prof. J. Poborskiego

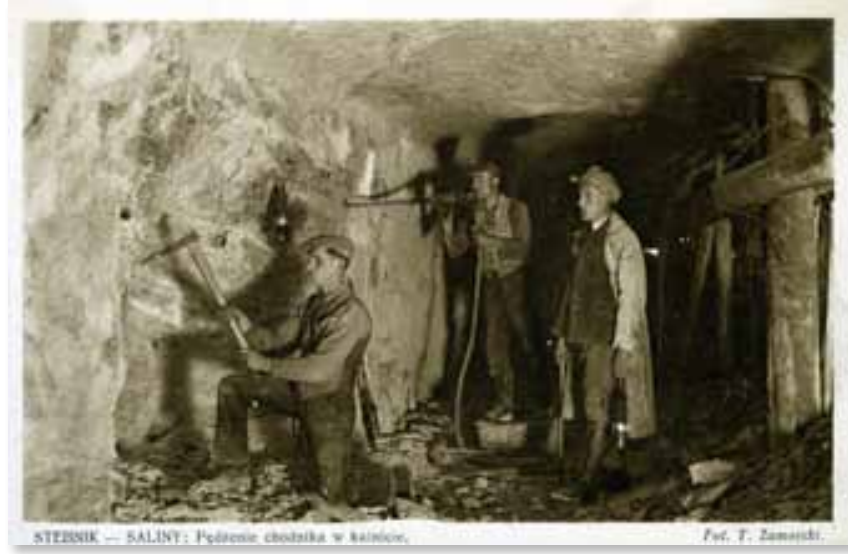

Fig. 9. A corridor excavated in the kainite seam. The Stebnyk mine in the interwar period (postcard from the collection of Museum of Cracow Salt-Works at Wieliczka • Pędzenie chodnika w kainicie. Kopalnia w Stebniku, lata międzywojenne (pocztówka ze zbiorów Muzeum Żup Krakowskich, Wieliczka)

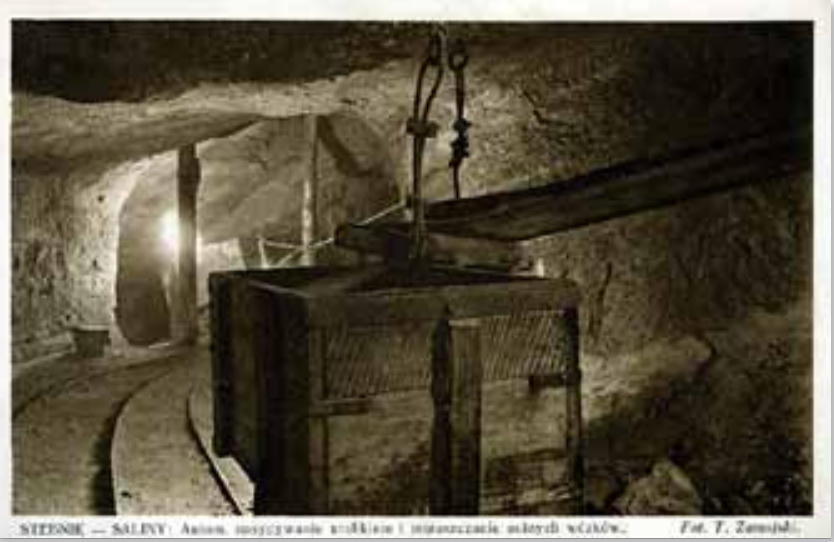

Fig. 10. Automatic infill and moving of loaded cars. The Stebnyk mine in the period between World War I and II (postcard from the collection of Museum of Cracow Salt-Works at Wieliczka) • Automatyczne nasypywanie urobkiem i popuszczanie pełnych wózków. Kopalnia w Stebniku, lata międzywojenne (pocztówka ze zbiorów Muzeum Żup Krakowskich, Wieliczka)

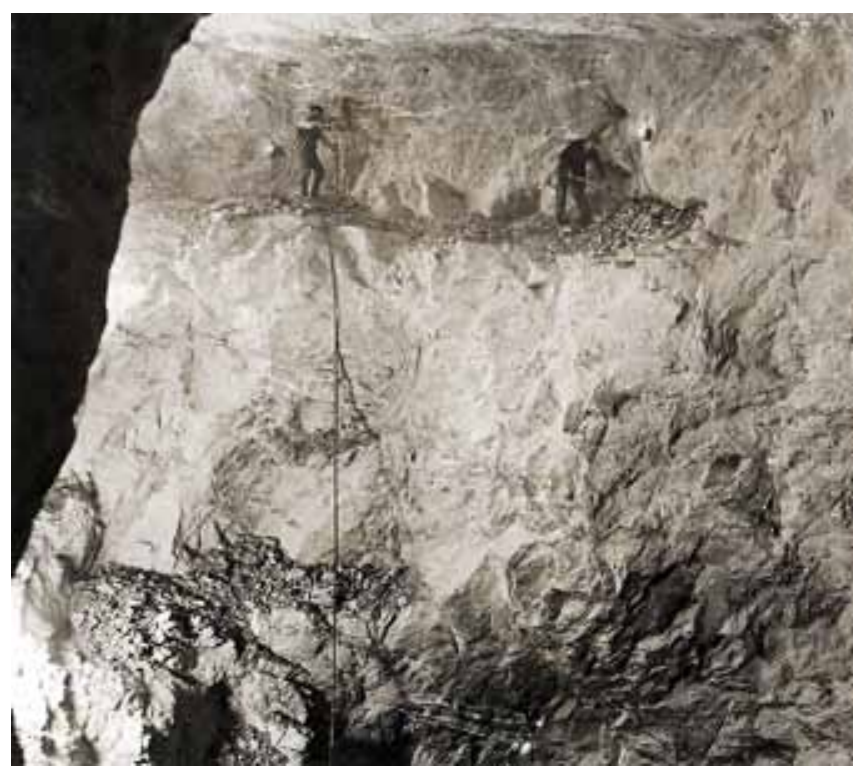

Fig. 12. Reconstructed chamber in the Stebnyk mine. Photo from private archive of Prof. J. Poborski - Kopalnia Stebnik - komora w odbudowie. Fot. z prywatnego archiwum prof. J. Poborskiego 


\section{References (Literatura)}

Alth, A., 1871. Pogląd na źródła słone i naftowe tudzież na warzelnie sol kuchennej w Galicyj i Bukowinie. Sprawozdanie Komisyi Fizyograficznej c.k. towarzystwa naukowego krakowskiego, V: 49-93. (In Polish only)

Andreyeva-Grigorovich, A.S., Oszczypko, N., Savitskaya, N.A., Ślączka, A. \& Trofimovich, N.A., 2003. Correlation of Late Badenian salts of the Wieliczka, Bochnia and Kalush areas (Polish and Ukrainian Carpathian Foredeep). Annales Societatis Geologorum Poloniae, 73: 67-89.

Andreyeva-Grigorovich, A.S., Oszczypko, N., Ślączka, A., OszczypkoClowes, M., Savitskaya, N.A. \& Trofimovich, N.A., 2008. New data on the stratigraphy of the folded Miocene Zone at the front of the Ukrainian Outer Carpathians. Acta Geologica Polonica, 58, 3: 325-353.

Bukowski, K. \& Jackiewicz, A., 1926. Sól i saliny polskie. Dyrekcja Salin Państwowych. Ministerstwo Przemysłu i Handlu, Warszawa, 107 pp. (In Polish only)

Czapowski, G., Bukowski, K. \& Poborska-Młynarska, K., 2009. Miocene rock and potash salts of West Ukraine. Field geological-mining seminar of the Polish Salt Mining Society. Geologia (Przegląd Solny 2009), Wyd. AGH, Kraków, 35, 3: 479-490. (In Polish, English summary)

Hauer, C., 1870. Über den Kainit v. Kalusz in Galizien. Jahrbuch der K. K Geologische Reichsanstalt, XX, $141 \mathrm{pp}$.

Hryniv, S.P., Dolishniy, B.V., Khmelevska, O.V., Poberezhskyy, A.V. \& Vovnyuk, S.V., 2007. Evaporites of Ukraine: a review. Geological Society, London, Special Publications, 285: 309-334.

Jodłowski, A., 1971. Salt Exploitation in Little Poland in Prehistoric time and the Early Middle Ages. Studia i materiały do dziejów żup solnych w Polsce. T. IV, Wieliczka, 316 pp. (In Polish, English summary)

Kamieński, Z., 1911a. O wytwórczości soli. Przyczynek do dziejów żup galicyjskich. Przewodnik naukowo-literacki, 39: 85-96, 176-192, $257-$ 263. (In Polish only)

Kamieński, Z., 1911b. Żupy solne w Galicji. Przeglad techniczny, 49: 328 330, 353-356, 372-374, 399-402. (In Polish only)

Kityk, W.I., 1979. Disgarmonitchnyje skladki odsadotchnych tolsch. Opyt morfologitcheskoy tipizacyi. Naukovaya Dumka, Kiyev, 127 pp. (In Russian only)

Kityk, W.I., Bokun, A.N., Panov, G.M., Slivko, E.P. \& Schaydietskaya, W.C., 1983. Galogennye formacyi Ukrainy: Zakarpatskiy progib. Naukovaya Dumka, Kiyev, 160 pp. (In Russian only)

Kityk, W.I., Petrychenko, O.I., Polkunov, W.F., Roskotch, Y.T., Slivko, E.P. \& Tastch, W. M., 1971. Putevoditel ekskursyi simpozyuma po problemie "Galogennye formacji Ukrainy i sviazannye s nimi poleznye iskopayemye". Naukovaya Dumka, Kiyev, 63 pp. (In Russian only)

Kleczkowski, A.S., 1981. Wpływ regionalnych warunków geologicznych na poglądy o genezie solanek w Polsce (poza Karpatami). Prace Muzeum Ziemi, z. 34: 77-79. (In Polish only)

Koriń, S.S., 1994. Geological outline of Miocene salt-bearing formations of the Ukrainian fore-Carpathian area. Przeglad Geologiczny, 42: 744747. (In Polish, English summary)

Kotarba. M. J., 2009. The Starunia palaeontological site and idea of the Ukrainian-Polish trans-border geotourist trail "Traces of large extinct mammals, earth wax, oil and salt: from Starunia to Kraków", Geoturystyka, This volume.

Kulyniak, D., 2002. Chemical plant in Lviv Oblast poses danger to Stebnyk region. The Ukrainian Weekly, 14.07.2002.

Oszczypko, N., 2006. Development of the Polish sector of the Carpathian Foredeep. Przeglad Geologiczny, 54: 396-403. (In Polish, English summary)

Permiakov, R.S., Romanov, W.S. \& Bieldy, M.P., 1981. Technologiya dobyci soliey. Izd. Niedra, Moskva, 272 pp. (In Russian only)

Petryczenko, O.I., Panow, G.M., Peryt, T.M., Srebrodolski, B.I., Pobereżski, A.W. \& Kowalewicz W.M., 1994. Outline of geology of the Miocene evaporite formations of the Ukrainian part of the Carpathian Foredeep. Przeglad Geologiczny, 42: 734-737. (In Polish, English summary)

Poborska-Młynarska, K. \& Andrusikiewicz, W., 2010. Exploitation of the potash deposits in eastern Małopolska during Second Polish Republic - the contribution to the history of salt mining in the Sub-Carpathian region. Geologia (Przegląd Solny 2010), Wyd. AGH, Kraków, 36, 3: 273-285. (In Polish, English summary)

Pusch, G.G., 1831-1836. Geognostische Beschreibung von Polen so wie der übrigen Nordkarpathen-Ländern. I (1831), II (1836). J. G. Cotta Buchh. Stuttgart u. Tübingen, $338 \mathrm{pp}$.

Pusch, G.G., 1844. Ważna wiadomość o nowo odkrytych ogromnych pokładach soli kamiennej pod Stebnikiem w Galicji wschodniej. Biblioteka Warszawska, t. IV: 205-209. (In Polish only)

Rumpf, J., 1872. Ueber den Kaluszit, ein neues Mineral v. Kalusz. Mineralogische Mittheilungen, 2: 117-124.

Staszic, S., 1815. O ziemiorództwie Karpatów i innych gór i równin Polski. Warszawa, (Reprint Wydawnictwa Geologiczne, 1955), 390 pp. (In Polish only)

Szajnocha, W., 1891. Źródła mineralne Galicji, pogląd na ich rozpołożenie, skład chemiczny i powstanie. Rozprawy Wydziału MatematycznoPrzyrodniczego AU, t. XXII, Kraków, 111 pp. (In Polish only)

Szajnocha, W., 1893. Kopalnie i warzelnie soli w Galicji. Przewodnik Naukowy i Literacki, (Supplement 4, Gazeta Lwowska), Lwów, t. XXI: 602-610. (In Polish only)

Webner, (?), 1872. Grubenkarte des Kalisalzbergwerkes zu Kalusz.

Werner, Z., 1977. Złoża soli potasowych. W: Surowce mineralne świata $\mathrm{K}_{2} \mathrm{O}-\mathrm{Br}-\mathrm{J}-\mathrm{N}$ (ed. Bolewski A.), Warszawa. 144 pp. (In Polish only)

Wiadomość o soli w Stebnika. 1844. Kuryer krakowski. (In Polish only)

Windakiewicz, E., 1871. Pokłady chlorku potasu (sylwinu) w kopalni kaluskiéj w Galicyi. Sprawozdanie Komisyi Fizyograficznej c.k. towarzystwa naukowego krakowskiego, Kraków, V: 45-48. (In Polish only)

Windakiewicz, E., 1926. Solnictwo, sole kamienne, potasowe i solanki, ich własności, fizjografia, górnictwo i warzelnictwo. Kraków. T. I-IV: 1140 pp. (In Polish only)

Windakiewicz, E., 1939. Występowanie soli w Polsce. AGH Kraków. Życie Techniczne, 1-2: 41-50. (In Polish only)

Zaręczny, S., 1894. Atlas Geologiczny Galicji. Tekst do zeszytu trzeciego. Komisja Fizjograficzna Akademii Umiejętności, Kraków. 290 pp. (In Polish only) 